\title{
LAS ARTES PLÁSTICAS COMO MEDIO ARTICULADOR DEL CURRÍCULO ESCOLAR
}

\author{
Alba Fernández Zamora' \\ Ligia Angulo Hernández²
}

\section{Resumen}

Este ensayo se basa en la experiencia realizada por una maestra, en la cual integra el currículum, correlacionando las disciplinas de la matemática, ciencias, estudios sociales y español a través de los elementos del lenguaje plástico. La experiencia se desarrolló en una escuela rural costarricense.

Palabras claves: artes plásticas, arte infantil, creatividad y educación.
Abstract

This article recounts a teacher's experience who integrates the curriculum, through the correlation of elements of plastic art with other subjects such as Math, Science, Social Studies and Spanish. This experience was developed in a Costa Rican rural school.

Keywords: art, plastic art, children's art, creativity, education.

\section{Justificación}

\section{L}

a experiencia se inicia en el momento de realizar la práctica supervisada 2004. Esta se desarrolló en la escuela Peters, ubicada en San Juan de Sarchí, Alajuela y el tipo de escuela es Dirección 1.

1 Maestra en I y Il ciclos con énfasis en educación rural, Profesora de Artes Plásticas. Técnico en artesanias textiles. Experiencia con proyectos en la Casa de la Cultura en Barva, Heredia, Municipalidad de San José, Club de Leones en Sarchi y Embajada de Japón con trabajos con niños y niñas de comunidades urbanas y rurales.

2 Máster en Docencia. Licenciatura en ciencias de la educación con énfasis en I y II ciclos. Experiencia en educación primaria, informática educativa y educación de adultos. Actualmente es académica e investigadora de la División de Educación Rural.

Recibido: 2 de noviembre-2006 - Aprobado: 30 de noviembre-2006 
Estaba nombrada en esa escuela como profesora de Artes Plásticas a tiempo completo con todos los niveles escolares; para poder realizar la práctica pedagógica, se solicitó permiso a la unidad académica de la DER, para desarrollar el currículo a través de las lecciones de artes plásticas en el primer ciclo escolar.

Dicha práctica consistió en integrar el currículum, correlacionando las disciplinas de la matemática, ciencias, estudios sociales y español a través de los elementos del lenguaje plástico.

Conscientes de la vital importancia de la educación artística, porque genera la expresión creadora innata que todo ser humano trae consigo, a la vez lo incentiva, estimula sus potencialidades, las cualidades, los valores socioculturales, espirituales, morales y psicológicos del individuo, se hace necesario que, desde la edad escolar se estimule el intelecto de los niños y las niñas con el fin de que desplieguen su creatividad en todos los ámbitos cognitivo, socioafectivo y psicomotriz.

Los niños y las niñas construyen las sensaciones, percepción visual, táctil o auditiva hasta llegar a la etapa del conocimiento operacional y abstracto. Esto les permite desenvolverse y manifestarse en el ámbito escolar y familiar, logrando la integración natural para aceptarse como persona capaz de enfrentar las distintas situaciones de la vida cotidiana y formar parte de la sociedad. De aquí la importancia de integrar el arte al currículo escolar, porque contribuye no sólo a forjar la personalidad, la sensibilidad, sino también como medio para expresar los pensamientos, sentimientos, expresión creadora, crítica y autonomía.

\section{Metodología}

Basados en los pilares fundamentales de educación propuestos por Jacques Delors, la educación debe reestructurarse en torno a cuatro aprendizajes fundamentales, que en el transcurso de la vida serán para cada persona, los pilares del conocimiento, y que son mencionados a manera de resumen a continuación:

- Aprender a conocer, es adquirir los instrumentos de la comprensión.

- Aprender hacer, para poder influir sobre el propio entorno.

- Aprender a vivir juntos, para participar y cooperar con los demás en todas las actividades humanas. 
- Aprender a ser: este es un proceso fundamental que recoge los elementos anteriores, para que florezca la personalidad y se esté en condiciones de obrar con creciente capacidad de autonomía, de juicio y de responsabilidad personal; sin menospreciar las posibilidades de cada individuo: memoria, razonamiento, sentido estético, capacidades físicas...

Si el arte contribuye a forjar la personalidad del individuo, cumple con el principio del conocimiento Aprender a ser, ya que en este la relevancia es el florecimiento de la personalidad y que el individuo esté en capacidad de actuar con autonomía, con juicio y responsabilidad personal.

\section{Fundamentación teórica de la educación artística}

La educación artística se fundamenta en diversos conceptos de arte, los cuales son necesarios para afrontar el concepto que se quiere brindar en el proceso educativo. Es conveniente también considerar el contacto con lo autóctono, con los primeros residentes de nuestro territorio y, por lo tanto, constructores de nuestra identidad, así como las culturas no occidentales que enriquecen y diversifican el concepto artístico-plástico. Por medio de las Artes Plásticas, desarrolladas a través del currículum escolar, el Ministerio de Educación Pública pretende, entre otras consideraciones, que el estudiante de enseñanza general básica sea capaz de resolver tareas y problemas creativamente, que utilice las artes como recurso interdisciplinario, desarrollar habilidades y destrezas con imaginación, así como interrelacionar y correlacionar el arte con otras áreas del saber.

\section{Propuesta pedagógica}

Para ejecutar la experiencia de la articulación de las artes plásticas como medio para desarrollar el currículum escolar, se solicitaba a la maestra encargada del grupo los objetivos y contenidos correspondientes a determinada semana. Estos objetivos y contenidos del programa de primaria se relacionaban con los objetivos y contenidos del plan de estudio de Artes Plásticas. Dos ejemplos de la correlación entre ambos planes de estudio en las asignaturas de ciencias y estudios sociales se detallan a continuación. Es importante indicar que la experiencia fue desarrollada en todas las asignaturas del currículo escolar y que por razones de brevedad, se comparten únicamente estas. 


\begin{tabular}{|c|c|c|c|}
\hline $\begin{array}{l}\text { Plan de Estudios de } \\
\text { Primaria para I Ciclo }\end{array}$ & \multicolumn{3}{|c|}{$\begin{array}{c}\text { Plan de Estudios } \\
\text { Artes Plásticas I y II Ciclos }\end{array}$} \\
\hline $\begin{array}{l}\text { Asignatura: Ciencias. } \\
\text { Eje Temático: Conozco } \\
\text { mi cuerpo. }\end{array}$ & \multicolumn{3}{|c|}{ Unidad de estudio: Concepto de salud en la obra de arte. } \\
\hline $\begin{array}{l}\text { Objetivo: } \\
\text { Analizar el abuso físico, } \\
\text { psicológico, sexual y sus } \\
\text { repercusiones en la salud. }\end{array}$ & $\begin{array}{l}\text { Objetivo: Aplicar } \\
\text { en la obra artístico } \\
\text { plástica el concep- } \\
\text { to de autoestima. }\end{array}$ & $\begin{array}{c}\text { Técnica: } \\
\text { El autorretrato. }\end{array}$ & \multirow{2}{*}{$\begin{array}{l}\text { Productos: } \\
\text { Confección } \\
\text { instrum entos } \\
\text { con material de } \\
\text { desecho, ejem- } \\
\text { plo: pincel elabo- } \\
\text { rado con espuma, } \\
\text { mecate y un palo } \\
\text { (muñeca). } \\
\text { Autoesculturas. }\end{array}$} \\
\hline $\begin{array}{l}\text { Contenido: } \\
\text { El abuso fisico, psi- } \\
\text { cológico y sexual. }\end{array}$ & $\begin{array}{l}\text { Contenido: au- } \\
\text { toestima en la obra } \\
\text { de arte. }\end{array}$ & $\begin{array}{l}\text { Materiales: } \\
\text { Hojas blancas, } \\
\text { lápices de colores, } \\
\text { témperas, pince- } \\
\text { les, plasticina, bo- } \\
\text { tellas plásticas. }\end{array}$ & \\
\hline
\end{tabular}

\section{Resultados de la articulación}

Autorretrato con mascota: Se inicia con el concepto de autorretrato. Se puede elaborar mirando una fotografia personal, mirándose a un espejo o describiéndose a sí mismo. Como actividad innovadora, se presenta a los niños la lámina con el autorretrato de la pintora mexicana Frida Kalho, la cual se dibujó rodeada de monos por su amor a la naturaleza y la cultura mexicana y seguidamente se narra la biografia de la pintora y se escucha la canción de Marco Vidal "El Pavo Real".

Los niños se miran a un espejo haciendo la diferencia entre observar y ver para dibujarse con su mascota o animal preferido. Estas actividades de mediación permitieron sensibilidad de parte de los niños y las niñas ante los animales en abandono o en vías de extinción, así como aprecio por la propia producción y el goce estético y, sobre todo, aceptarse a sí mismo y a los demás. 


\begin{tabular}{|c|c|c|c|}
\hline $\begin{array}{c}\text { Plan de Estudios } \\
\text { de Primaria para } \\
\text { I Ciclo }\end{array}$ & \multicolumn{3}{|c|}{$\begin{array}{l}\text { Plan de Estudios } \\
\text { Artes Plásticas I y II Ciclos }\end{array}$} \\
\hline $\begin{array}{l}\text { Asignatura: Estu- } \\
\text { dios sociales. } \\
\text { Eje Temático: } \mathrm{Mi} \\
\text { patria. }\end{array}$ & \multicolumn{3}{|c|}{ Unidad de estudio: Técnicas artístico-plásticas y artesanales. } \\
\hline $\begin{array}{l}\text { Objetivo: } \\
\text { Explicar el signifi- } \\
\text { cado e importancia } \\
\text { del patrimonio } \\
\text { histórico-cultural de } \\
\text { mi provincia. }\end{array}$ & $\begin{array}{l}\text { Objetivo: Impulsar } \\
\text { la aplicación de tra- } \\
\text { diciones culturales, } \\
\text { valores artísticos, } \\
\text { folclor mediante el } \\
\text { estudio del arte in- } \\
\text { digena costarricen- } \\
\text { se. }\end{array}$ & $\begin{array}{l}\text { Técnicas: } \\
\text { Planografia: Tiras } \\
\text { y papeles o cartuli- } \\
\text { nas con los que se } \\
\text { forman diseños de } \\
\text { distintos relieves. } \\
\text { Tridimensional: } \\
\text { Máscara o caretas. } \\
\text { Diseño textil como } \\
\text { el telar. }\end{array}$ & \multirow[t]{2}{*}{$\begin{array}{l}\quad \text { Productos: } \\
\text { Elaboración de } \\
\text { goma a partir de al- } \\
\text { midón de yuca. } \\
\text { Telar de cartón para } \\
\text { confeccionar un ta- } \\
\text { piz decorativo. } \\
\text { Máscaras con dis- } \\
\text { tintos personajes. } \\
\text { Sello con diseños } \\
\text { indigenas para rea- } \\
\text { lizar estampados. }\end{array}$} \\
\hline $\begin{array}{l}\text { Contenido: } \\
\text { Patrimonio histórico- } \\
\text { cultural de la pro- } \\
\text { vincia: significado e } \\
\text { importancia. }\end{array}$ & $\begin{array}{l}\text { Contenido: Arte y } \\
\text { cultura, patrimonio } \\
\text { cultural: tradicio- } \\
\text { nes, costumbres, } \\
\text { identidad y arte- } \\
\text { sanias. }\end{array}$ & \begin{tabular}{l}
\multicolumn{1}{c}{ Materiales: } \\
Cartón de caja, \\
tiras de tela, fibras \\
vegetales como el \\
vástago de plantas \\
de banano, papel \\
construcción, \\
témperas, papel \\
higiénico, papel \\
periódico.
\end{tabular} & \\
\hline
\end{tabular}

\section{Resultados de la articulación}

Planografía: Se rescata la tradición de la goma de almidón de yuca a partir de la importancia de este tubérculo en la dieta de nuestros indígenas. El telar ejemplifica cómo nuestros antepasados lo utilizaban para la confección de telas, que serían empleadas en sus vestuarios. Se tiñen hilos con plantas (azul de mata) y con la tinta de un caracol llamado "maurice". Planta que utilizaban las culturas bribri y cabécar de la corteza del árbol "mastate". La confección de las máscaras y caretas permitió ilustrar bailes y festividades de la época como el baile del diablito. 
Los sellos elaborados en cartón sirvieron de muestra como un artículo de carácter religioso que utilizaban los antepasados en eventos especiales, para decorar su piel.

\section{Conclusiones}

Cabe rescatar que las conclusiones de esta experiencia fueron de carácter vivencial al estar en contacto con los niños y las niñas, observar tanto en las clases como en los recreos cambios significativos. Además, se constatan los resultados por medio de las conversaciones con otros docentes a cargo del grupo y manifestaciones positivas de padres y madres de familia acerca de la labor pedagógica desarrollada. Algunas de estas evidencias que el niño o la niña logró manifestar a través de las Artes Plásticas son las siguientes:

- Algunos niños introvertidos logran comunicarse y desenvolverse de una manera más social con el resto del grupo. Dan a conocer sus creaciones artísticas tanto a los compañeros del mismo grupo como a otros docentes de la escuela. Pierden esa timidez que los caracterizaba participando de eventos públicos como actos cívicos.

- Mejoría en la ubicación espacial y los rasgos en las letras al trabajar con materiales concretos tales como: papel maché, engrudos (goma con papel), témperas.

- Seguridad para expresarse libremente tanto en forma oral como escrita al narrar cuentos ilustrados con creaciones personales, diseño y color.

- En algunos niños migrantes, hay indicios de que la autoestima mejoró, al aceptarse tal y como son, sintiéndose orgullosos de ser capaces de realizar un autorretrato.

- Un niño diagnosticado con problemas de tartamudez participa en exposiciones orales, donde el temor de pronunciar no era una falta personal, sino cometido por el muñeco (títere), situación que lo estimula sin sentir temor de ser ridiculizado.

- Los niños manifiestan denuncias sociales (ausencia de la familia, agresión intrafamiliar, pobreza, otros) a través de obras pictóricas.

- Desarrolla la descodificación de imágenes variadas, proporcionando una forma distinta de alfabetización visual.

- El arte va más allá que dibujar y colorear una fotocopia o una imagen, un momento de ocio, entretenimiento o terapia, el arte contribuye a la 
formación integral de las personas, desarrolla sensibilidad, capacidad creativa y percepción.

- Las artes plásticas permiten a cualquier educador desarrollar en sus estudiantes habilidades y destrezas, desarrollar la invención e imaginación, contribuyendo a la construcción de la personalidad y su relación con su contexto sociocultural urbano y rural.

\section{Recomendaciones}

Se propone un espacio para construir galerías de arte infantil permanente, tanto en las instituciones escolares como en el ámbito regional o nacional. Esto con el objetivo de estimular el arte en los niños y las niñas desde la edad temprana. Espacio que permitiría la manifestación de sus necesidades e intereses. Actualmente no existe ninguna propuesta del Ministerio de Educación o del Ministerio de Cultura, Juventud y Deportes.

Darles a los niños y las niñas la oportunidad para que participen como actores en "teatros para la educación". Esto permitiría desarrollar objetivos y contenidos de las distintas asignaturas del currículum escolar y aplicar las artes plásticas como medio articulador entre estas.

En la actualidad, se le da mucho auge al área de las ciencias "ferias científicas", relegando las artes a un segundo plano. Es importante rescatar por medio de los "festivales de creatividad" la coordinación entre centros educativos y comunidades para que a partir del arte se promueva el rescate de valores y la cultura nacional.

\section{Glosario}

Arte: El arte es una creación del espíritu humano, una manifestación que emana del uso de los sentidos y de la fuerza intelectual e inteligente, cargada de ideas formas, es una actividad humana que está esencialmente formada para el hombre, y como se dirige a los sentidos, se nutre más o menos de lo sensible, tiene fin en sí mismo.

Artes plásticas: Es una disciplina que permite por medio del logro, descubrir las fortalezas y el talento del niño y la niña, de la capacidad creadora donde el estudiante sea capaz de transformar una simple tarea (refiérase a simple la ejecución y no el acto pedagógico) en toda una aventura creativa.

Obra de arte: Se define de acuerdo con sus características, como aquella representación con carácter estético, que va dirigida a crear sensaciones, 
emociones y provoca el uso de los sentidos. Es aquella que puede impactar, que crea un discurso interior y provoca reflexión. La obra de arte es de carácter contemplativa y reflexiva.

Obra de arte infantil: Es el producto de la espontaneidad que muestra todo lo grande y bello del mundo de las ideas del niño y la niña.

Creatividad: Es una manifestación del espíritu que se caracteriza por poseer espontaneidad, talento e ingenio; se requiere para su desarrollo libertad y conocimiento. Se desarrolla y se estimula.

Educación artística: Es un modelo educativo que impulsa el desarrollo de la creatividad, que no limita el desarrollo de la personalidad, ni inhibe la libre expresión, es de carácter abierto, por lo que tiene una relación orgánica con las ciencias y las manifestaciones de la cultura. Es retroalimentativa.

Lenguaje plástico: Son todos los elementos que componen el diseño, como el color, la degradación tonal, el claroscuro, la línea, las texturas y las formas alternativas (estampas, imágenes...). La plasticidad en el arte es una representación que tiene que ver con el material, deviene de las armonías de las mezclas. 


\section{REFERENCIAS}

Anzorena, H. (1998). Ver para comprender: educación desde el arte. Buenos Aires, Argentina: Editorial Magisterio del Río de la Plata.

Jacques, D. (1996). La educación encierra un tesoro. México D. F.: UNESCO.

Ministerio de Educación Pública. (2005). Plan de Estudios para las Artes Plásticas en I y II ciclos. San José, Costa Rica.

Piaget, J. (1993). Psicologia del niño. Madrid: Ediciones Morata.

Vega, Roberto. (1996). Escuela, teatro y construcción del conocimiento. Buenos Aires, Argentina: Ediciones Santillana. 